\title{
Finger Millet in Tribal Farming Systems Contributes to Increased Availability of Nutritious Food at Household Level: Insights from India
}

\author{
Aliza Pradhan $^{1}$ (D) Akshaya Kumar $\operatorname{Panda}^{1} \cdot$ R. V. Bhavani ${ }^{1}$
}

Received: 29 July 2018/Accepted: 11 October 2018/Published online: 7 March 2019

(C) The Author(s) 2019

\begin{abstract}
The challenge to food production posed by climate aberrations has been seeing increased attention to reviving millet-based farming systems. Millets are climate-resilient and nutritionally equivalent or superior to most other cereals, making them a favourable crop to address the prevalence of malnutrition. Finger millet (Eleusine coracana) is among the major crops cultivated in the undulating terrains of Koraput district of Odisha, India. It is consumed as a staple food and drink by the local tribal communities. However, over the years there has been rapid decline both in area and in production of the crop leading to reduced grain availability for household consumption. With a view to increase the productivity, the study assessed the effects of possible combinations of crop varieties and agronomic practices that can be customized for finger millet production system in Koraput over 2 years (2015-2017). The study focused on crop productivity, profitability and labour requirement along with nutrition awareness initiatives. On-farm trial with improved variety 'GPU-67' with line transplanting and recommended fertilizer management in 2015-2016 showed 31 and 50\% higher grain yield and profit than that of farmers' practice (1579 $\mathrm{kg} \mathrm{ha}^{-1}$ and ₹ $13,730 \mathrm{ha}^{-1}$, respectively) and was counted as a recommended cultivation package. In 2016-2017, the recommended practice showed 60\% higher grain yield and 1.16 times more profit than farmers' practice $\left(1575 \mathrm{~kg} \mathrm{ha}^{-1}\right.$ and ₹ $14,000 \mathrm{ha}^{-1}$, respectively) $(P<0.000)$. Both total and women's labour requirement per ha was lower under recommended practice. An endline survey in 2017 revealed improved household consumption over baseline.
\end{abstract}

Keywords Finger millet · Nutritive food · Labour requirement · Household consumption · Subsistence agriculture · Tribal communities

\section{Introduction}

Agriculture productivity and production is adversely affected due to uneven weather conditions, increased temperature and changing rainfall pattern (onset, quantity and intra-seasonal distribution). Global food and nutrition transition focuses on unique interventions to feed the projected population of 9 billion in 2050, equitably, healthily and sustainably [1]. The World Summit on Food Security,

Aliza Pradhan

alizapradhan@gmail.com

1 M S Swaminathan Research Foundation, Chennai 600113, India
2009 , estimated that at least $70 \%$ more food production is required by 2050 to feed the ever increasing population. It would require an annual increase of approximately 44 million tons, which is $38 \%$ above current annual increase in food production [18]. Climate change together with rapidly increasing population is mounting considerable pressure on agriculture sector to improve productivity. The impact will be more pronounced in the hot tropics, mainly populated by developing countries as they are likely to suffer maximum loss in food production [3]. Further, a large population in developing countries is suffering from nutritional imbalance and prevalence of multiple micronutrient deficiencies [16, 19]. In this context, improvements in agricultural productivity leading to greater availability of nutritious food at household level 
can help address nutrition maladies. One possible solution is identifying and improving the yield of traditional or native crops that are highly adaptive to local climate, have high nutrient value and can efficiently withstand biotic and/ or abiotic stresses. These crops largely consumed by indigenous communities across the globe are often referred to as coarse cereals. One such crop, finger millet (Eleusine coracana L.) is a major staple crop among tribal farming communities in developing countries like India. Grown in arid regions, they can adapt to adverse climatic conditions, require minimal inputs and possess superior nutritional properties $[6,8]$. The crop has gained focus of scientific research for their extraordinary potential to grow under high temperature, low moisture and poor soils [15]. It is no more called a coarse cereal rather referred to as a nutricereal or as a nutraceutical crop and is seen as a potential solution for addressing malnutrition and hidden hunger worldwide [7].

Finger millet is high in $\mathrm{Ca}, \mathrm{Fe}$ and $\mathrm{Mg}$ and contains amino acid methionine, which are deficient in the diets of nutritionally insecure households dependent primarily on starchy staples such as polished rice or maize [4]. Its dietary fibre and mineral contents are also markedly higher than rice and maize (Table 1). In addition, shorter duration and suitability to grow in all seasons make finger millet a desirable crop in an intensive cropping system. The seeds have an extended shelf life without significant damage by storage pests, which makes them a good reserve for famine-prone periods and areas [17]. Crops such as rice and maize might provide food security, but finger millet accounts for manifold securities including food, fodder, fibre, nutrition, health, environment and livelihood at minimal cost, offering great opportunities for food and nutrition security [7].

Koraput district in the state of Odisha in India is characterized by warm and humid climate with $80 \%$ of the total annual rainfall received from the south-west monsoon in the months from June to mid-October. The annual average rainfall varies between 1320 and $1520 \mathrm{~mm}$. The mean daily maximum temperature is around $40{ }^{\circ} \mathrm{C}$, while the mean daily minimum temperature is around $14{ }^{\circ} \mathrm{C}$. Major soil type found in the area is matured red lateritic soil (Alfisols), mixed grey soil (Inceptisols) and unaltered soils with coarse parent materials (Entisols). The prevailing soil texture in the area is mostly sandy loam. Agriculture is primarily rainfed, and kharif (June-September) is the main cropping season. Finger millet is a major staple food crop, second only to paddy, among subsistence farming households in the rainfed uplands of the district. Area under finger millet accounts for $16 \%$ of the total gross cropped area and $28 \%$ of the total area under cereal crop cultivation in the district [5]. The tribal communities predominantly cultivate local landraces of finger millet, viz. telugu mandia, dasara mandia, san mandia and bada mandia, using traditional agronomic practices. Millets are mostly raised in kharif (June-September) on marginal lands in the upland and hilly regions with few or no external inputs, either as a pure crop or with a range of pulses, legumes and oilseeds under mixed cropping systems. Besides its importance as a nutritious food crop, finger millet contributes greatly to the incomes of rural households. It is sold directly as grain or brewed into local beer for sale in local markets where there is ready demand. Despite great value associated with this nutri-crop by the local communities, there has been decline both in area and in production of the crop. The area under finger millet cultivation in the district declined by $55 \%$ over three decades, from 144,480 hectares in 1980 to 65,160 ha in 2013 [5]. Further, due to traditional cultivation practices, the grain yield is as low as $4 \mathrm{q} \mathrm{ha}^{-1}$ under broadcasting method, and even with traditional transplanting methods yield, it is only $9 \mathrm{q} \mathrm{ha}^{-1}$ [11]. Some of the primary reasons are poor crop management (use of lowquality seeds, broadcasting method of sowing leading to low plant population, no nutrient and weed management practices), and in some cases replacement by commercial plantations of Eucalyptus; this has led to both reduced availability and consumption.

Table 1 A comparison of nutritional composition of finger millet with other major cereals

\begin{tabular}{|c|c|c|c|c|c|c|c|c|c|}
\hline \multirow[t]{2}{*}{ Cereal and millets } & \multicolumn{9}{|c|}{ Nutritional composition $^{a}$} \\
\hline & $\begin{array}{l}\text { Protein } \\
(\mathrm{g})\end{array}$ & $\begin{array}{l}\text { Fat } \\
(\mathrm{g})\end{array}$ & $\begin{array}{l}\text { Minerals } \\
(\mathrm{g})\end{array}$ & $\begin{array}{l}\text { Crude fibre } \\
(\mathrm{g})\end{array}$ & $\begin{array}{l}\text { Carbohydrates } \\
\text { (g) }\end{array}$ & $\begin{array}{l}\text { Energy } \\
\text { (Kcal) }\end{array}$ & $\begin{array}{l}\text { Calcium } \\
(\mathrm{mg})\end{array}$ & $\begin{array}{l}\text { Phosphorus } \\
(\mathrm{mg})\end{array}$ & $\begin{array}{l}\text { Iron } \\
(\mathrm{mg})\end{array}$ \\
\hline Finger millet & 7.3 & 1.3 & 2.7 & 3.6 & 72.0 & 328 & 344 & 283 & 3.9 \\
\hline $\begin{array}{l}\text { Rice, parboiled, } \\
\text { milled }\end{array}$ & 6.4 & 0.4 & 0.7 & 0.2 & 79.0 & 340 & 9 & 143 & 1.0 \\
\hline Rice, raw, milled & 6.8 & 0.5 & 0.6 & 0.2 & 78.2 & 345 & 10 & 160 & 0.7 \\
\hline Maize, dry & 11.1 & 3.6 & 1.5 & 2.7 & 66.2 & 342 & 10 & 348 & 2.3 \\
\hline Maize, tender & 4.7 & 0.9 & 0.8 & 1.9 & 24.6 & 125 & 9 & 121 & 1.1 \\
\hline
\end{tabular}

${ }^{\mathrm{a} A l l}$ values are per $100 \mathrm{~g}$ of edible portion [9] 
This study was undertaken as part of a feasibility study on Farming System for Nutrition, with the objective of improving availability of nutrient-dense crops at household level to address nutrition insecurity [2]. This paper examines the impact of efforts to revive the millet-based farming systems in the area primarily by improving the crop productivity, thereby contributing to increased availability of nutritious food at household level.

\section{Materials and Methods}

\section{Study Site}

A core set of seven villages (658 households with population of 2845) in Boipariguda block of Koraput district was selected for the study. Detailed baseline survey and focus group discussions were undertaken from June 2013 to September 2014, to capture information on socio-demographic and agricultural practices, nutritional status of the population and food consumption pattern [12].

\section{Agricultural Status}

The population of the study villages is predominantly dependent on agriculture for food and livelihood. About $73 \%$ of the village households reported either cultivation or agricultural labour as the primary occupation, and around $68 \%$ of the households reported the same as their secondary occupation. A majority of the households (530 out of 658) are marginal farmers with less than a hectare of land. Agriculture is largely rainfed, and kharif (JuneSeptember) is the main cropping season. Paddy is the predominant crop followed by finger millet, which is mostly raised on marginal lands in the upland and hilly regions with few external inputs, either as a pure crop or with a range of pulses, legumes and oilseeds under mixed cropping system.

\section{Nutritional Status and Food Consumption Pattern}

A majority, $30-40 \%$ of children and $40-50 \%$ of adults, were undernourished; high levels of anaemia ( $>60 \%)$ prevailed among children under five, adolescent girls and women (18-45 years) [12]. The diet was found to be largely cereal dominated with consumption of all other food groups being less than the recommended levels [12]. Finger millet was a part of the daily diet of most households; it was, however, largely being sourced from the market (71\%) and consumed in a diluted form.

\section{Nutrition Awareness Activities}

Several nutrition awareness initiatives were conducted throughout the study period to create better understanding on the basics of balanced diet and nutrition and how to access this from locally available natural resources and farming system (http://www.lansasouthasia.org/blog/neednutrition-awareness-transferring-food-field-plate). Selected men and women farmers from the villages were given training and capacitated on this aspect (http://www. lansasouthasia.org/content/refresher-course-community-hu nger-fighters). Initiatives specific to finger millet included awareness on nutrient content of the crop, organization of exposure visits to finger millet fields, trainings on improved agriculture practices, pest management and recipe demonstration.

\section{Participatory on-farm demonstration and selection of improved variety and recommended agronomic practice}

The baseline survey indicated demand-supply gap in the availability of finger millet; low productivity of the crop emerged as a primary agricultural factor for less availability of the crop for household consumption [12]. Accordingly, appropriate technologies/approaches to address the productivity issue were laid out in discussion with technical experts and men and women farmers. Under traditional practice, seeds of local land races of finger millet are broadcasted at a heavy seed rate of $25 \mathrm{~kg} \mathrm{ha}^{-1}$ as a safeguard against poor seed quality and uncertain soil moisture. Such seed rate under favourable soil moisture conditions results in a very dense crop, which is normally not thinned out and leads to crowded plant population. This leads to unequal nutrient availability to plants and difficulty in weeding. Traditional practice of cultivation also does not include application of manure or fertilizers or any other management practice. Under such circumstances, there is poor yield; seeds saved from these fields also turn to be of inferior quality with considerable physical mixing, which further adversely affects the yield potential.

With a view to address this, a farmer participatory OFD was conducted in seven farmers' field over 0.52 ha in kharif of 2015-2016 in order to select the suitable variety and appropriate agronomic practice for higher productivity. GPU-67, a high-yielding finger millet variety selected under a participatory varietal selection programme under an earlier study [10], was taken along with farmers' variety for comparison. GPU-67 is a semi-dwarf (non-lodging) medium-duration variety (114-118 days) with desirable traits like good panicle shape, no grain shattering and yield potential of 30-35 $\mathrm{q} \mathrm{ha}^{-1}$. Improved agronomic practices included were (a) nursery raising with recommended seed 
rate of $5 \mathrm{~kg} \mathrm{ha}^{-1}$; (b) line transplanting of 3-5-week-old seedlings; (c) population density @ $20 \mathrm{~cm} \times 10 \mathrm{~cm}$; (d) application of recommended dose of fertilizer 40:20:20 kg nitrogen $(\mathrm{N})$, phosphorous $(\mathrm{P})$ and potassium (K) per ha; and (e) timely weeding and need-based plant protection measures. Half of the nitrogen and total phosphorus and potash were applied over the main field as basal application. The remaining $50 \%$ of nitrogen was applied 25 days after transplanting, depending on availability of soil moisture.

Each farmer's field in the OFD was considered as a replicate, and the allotted area under each farmer was split into four treatments: farmers' method against recommended agronomic practice in different combinations resulting in the following four treatments $(T)$, viz.

$T_{1}$ : GPU-67 + recommended agronomic practices,

$T_{2}$ : Farmers' variety + recommended agronomic practices,

$T_{3}$ : GPU-67 + traditional farming practice, and

$T_{4}$ (control): Farmers' variety + traditional farming practice.

The land area was split into four equal portions to fit all the treatments. The study focused on collecting the data on yield-attributing parameters (number of productive fingers, finger length), crop yield and economics of production and comparing them among the treatments. Total cost of cultivation, gross return and net return were calculated. The cost of cultivation included paid expenses (for inputs and hired labour, if any) incurred during calendar of operations under crop production, and gross return was calculated by multiplying the total return with the market price of the crop. Net return was calculated by subtracting total cost of cultivation from gross return.

In 2016-2017, the best recommended practice was promoted, to bring more area under the crop. Thirty farmers following recommended practice and thirty farmers following farmers' practice were selected for comparison purpose. A gender-wise division of labour requirement across the entire calendar of operations was recorded and analysed. In rabi (October-January), farmers having irrigation facility were encouraged to grow a short-duration variety (103-105 days) of the crop, 'Bhairabi'.

\section{Endline Survey}

An endline survey was conducted in late 2017 taking a sample of 190 households from the study area. Comparison of food consumption pattern (quantity, frequency and source) was made between the same set of 190 households at the baseline and endline surveys of the study. All the data were analysed using SPSS software.

\section{Results and Discussion}

\section{On-Farm Demonstration of Finger Millet Cultivation (2015-2016)}

The OFD showed the technological potential to achieve improved grain yield under appropriate production management conditions. GPU-67 under improved agronomic practices $\left(T_{1}\right)$ produced the highest grain yield of $2067 \mathrm{~kg} \mathrm{ha}^{-1}, 31 \%$ higher yield than that of farmers' varieties under traditional agronomic practices (control; $P=0.038$ ) (Table 2). Further, reduced seed rate and increased grain yield in $T_{1}$ translated to a $50 \%$ increase in net return than that under control $\left(₹ 13,730 \mathrm{ha}^{-1}\right)$. The increased grain yield of $488 \mathrm{~kg}$ of finger millet per ha under $T_{1}$ as compared to $T_{4}$ will provide larger quantity of nutrient-rich food to farmer households, the crop being rich in micronutrient content, especially calcium, iron and folic acid. Considering all the above parameters, i.e., yield, economics and increased availability, improved variety of GPU-67 with improved agronomic practice was selected as the recommended variety for promotion and scale up in 2016-2017.

Table 2 Comparison of yield-contributing parameters, grain yield and economics of production among treatments in 2015-2016

\begin{tabular}{|c|c|c|c|c|c|c|}
\hline Treatments & $\begin{array}{l}\text { No. of productive } \\
\text { fingers plant }\end{array}$ & $\begin{array}{l}\text { Finger } \\
\text { length }(\mathrm{cm})\end{array}$ & $\begin{array}{l}\text { Grain yield } \\
\left(\mathrm{kg} \mathrm{ha}^{-1}\right)\end{array}$ & $\begin{array}{l}\text { Total cost of } \\
\text { cultivation }\left(₹ \mathrm{ha}^{-1}\right)\end{array}$ & $\begin{array}{l}\text { Gross } \\
\text { return }(₹)\end{array}$ & $\begin{array}{l}\text { Net } \\
\text { return } \\
\text { (₹) }\end{array}$ \\
\hline $\begin{array}{l}T_{1}: \text { GPU- } 67+\text { recommended agronomic } \\
\text { practices }\end{array}$ & 4.4 & 7.4 & $2067 *$ & 20,800 & 41,340 & 20,540 \\
\hline $\begin{array}{l}T_{2}: \text { Farmers' variety }+ \text { recommended } \\
\text { agronomic practices }\end{array}$ & 4.4 & 6.6 & 1832 & 20,670 & 36,640 & 15,970 \\
\hline $\begin{array}{l}T_{3}: \text { GPU- } 67+\text { traditional farming } \\
\text { practices }\end{array}$ & 4.3 & 6.6 & 1740 & 17,980 & 34,800 & 16,820 \\
\hline $\begin{array}{l}T_{4}(\text { Control): Farmers' } \\
\quad \text { variety }+ \text { traditional farming practices }\end{array}$ & 4 & 6.5 & 1579 & 17,850 & 31,580 & 13,730 \\
\hline
\end{tabular}




\section{Cultivation of Finger Millet Under Recommended Practice (2016-2017)}

\section{Kharif Cultivation of Finger Millet (2016-2017)}

In 2016-2017, GPU-67 with improved agronomic practices was cultivated by 238 farmers covering 27 ha upland area across the seven study villages. The results of comparison study between recommended and farmers practices $(n=30)$ showed a $60 \%$ higher grain yield in recommended practice than in farmer's practice $\left(1575 \mathrm{~kg} \mathrm{ha}^{-1}\right)$ $(P=0.0001)$; this was primarily due to the occurrence of higher number of productive fingers than that in the control plots under farmers' practice $(P=0.011)$ (Table 3). The recommended practice also had 1.16 times higher net return than control (₹ $14,000 \mathrm{ha}^{-1}$ ). This increase in production will significantly contribute to the nutritional food security of a very vulnerable community, with small land holdings. The yield increase also enhanced the grain availability for household consumption and generated surplus for sale. In addition, there was $35 \%$ increased straw yield under the recommended practice $(P=0.005)$ than under the control fields $\left(3295 \mathrm{~kg} \mathrm{ha}^{-1}\right)$; this will help in meeting the fodder requirement of the farm animals in the study area.

\section{Implications of New Agronomic Practices \\ in the Recommended Method on Labour Requirements}

Both total and women labour requirement were 5 and $35 \%$ lower under recommended practice than that under farmers' practice (146 and 116 labour days $\mathrm{ha}^{-1}$, respectively) (Fig. 1). There was no major change in labour requirement for land preparation under recommended and farmers' practices as in both cases the land was ploughed thoroughly 2-3 times within an interval of 8-10 days followed by levelling. However, sowing under recommended practice had 9.6 times more labour requirement than farmers' practice (5 labour days $\mathrm{ha}^{-1}$ ). Men were engaged in preparing the land for nursery and transportation of seedlings to the main field, and women were involved in sowing the seeds in nursery, uprooting, bundling and transplanting of the 20-25-day-old seedlings with a spacing of $25 \times 25 \mathrm{~cm}$ in the main field. The increased labour hours of women for transplanting under recommended practice was, however, largely offset by reduced labour required for weeding. Weed management, primarily done by women, was, by far, the most important preoccupation in finger millet production in the study region. A variety of weeds, mainly grasses (Eleusine indica, Digitaria sp., Cynodon dactylon, Cyperus sp., Panicum maximum), were reported to be the most obnoxious presence in finger millet fields because of their resemblance to the crop, which makes weeding very cumbersome, particularly under broadcasting method. Weed control was exclusively manual, using small short-handled hoes, and the efficiency was very low in broadcasted fields. Further, with paddy being the primary focus crop, the high labour requirement made timely weeding in finger millet untenable, resulting in the crop being severely stressed by weed competition leading to low yield. Transplanting facilitated inter-row and inter-plant

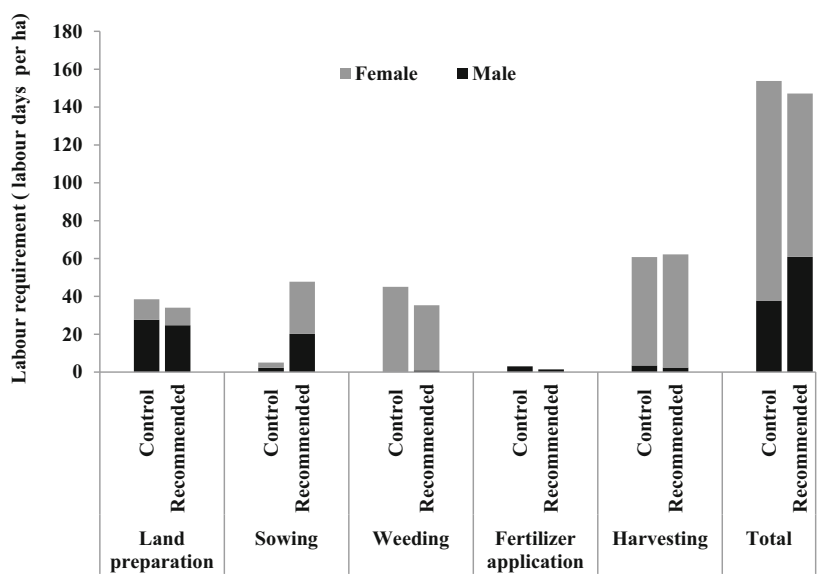

Fig. 1 Comparison of labour requirement across the calendar of operations between recommended and farmers' practices in 2016-17

Table 3 Comparison of yield-attributing characters, yields and economics of production between recommended and farmers' practices in 2016-2017 $(n=30)$

\begin{tabular}{|c|c|c|c|c|c|c|c|}
\hline Treatments & $\begin{array}{l}\text { No. of } \\
\text { productive } \\
\text { fingers plant }^{-1}\end{array}$ & $\begin{array}{l}\text { Finger } \\
\text { length }(\mathrm{cm})\end{array}$ & $\begin{array}{l}\text { Grain yield } \\
\left(\mathrm{kg} \mathrm{ha}^{-1}\right)\end{array}$ & $\begin{array}{l}\text { Straw yield } \\
\left(\mathrm{kg} \mathrm{ha}^{-1}\right)\end{array}$ & $\begin{array}{l}\text { Total cost of } \\
\text { cultivation } \\
\left(₹ \mathrm{ha}^{-1}\right)\end{array}$ & $\begin{array}{l}\text { Gross } \\
\text { return } \\
\text { (₹) }\end{array}$ & $\begin{array}{l}\text { Net } \\
\text { return } \\
\text { (₹) }\end{array}$ \\
\hline $\begin{array}{l}\text { Recommended practice } \\
\text { (GPU-67 + recommended } \\
\text { agronomic practices) }\end{array}$ & $2.92 \pm 1.16^{*}$ & $5.32 \pm 1.11$ & $2512.50 \pm 673.35^{* * *}$ & $4444.07 \pm 1197.73 * *$ & 19,970 & 50,240 & 30,270 \\
\hline $\begin{array}{l}\text { Control (farmers' } \\
\text { variety }+ \text { traditional farming } \\
\text { practices) }\end{array}$ & $1.97 \pm 0.96$ & $5.11 \pm 1.69$ & $1574.85 \pm 372.09$ & $3294.74 \pm 1090.03$ & 17,500 & 31,500 & 14,000 \\
\hline
\end{tabular}

$* P<0.05 ; * * P<0.01 ; * * * P<0.001$ 
space and made weeding less labour intensive. Harvesting of finger millet which involves collection of fingers one by one by cutting with a sharp instrument was done exclusively by women; the higher yield therefore led to a slight increase in labour requirement. The extent of increase was tempered by uniformity in plant growth, and the mature fingers did not get entangled, making it easier for the women to harvest. The findings were further substantiated by village-level focus group discussions conducted in early 2018. The common feedback was that transplanting in finger millet had reduced the labour burden for women primarily due to less time required under weeding, while the labour requirement had increased for men, mainly under nursery preparation and seedling transportation.

\section{Rabi Cultivation of Finger Millet (2016-2017)}

Finger millet was generally grown only during kharif (June-September) and in uplands. Farmers who did not have upland to grow the crop during kharif but had irrigation facility were encouraged to grow the crop in rabi (October-January) in medium lands. A short-duration (103-105 days) variety 'Bhairabi' was promoted following recommended package and practices resulting in a grain yield of $1340 \pm 240 \mathrm{~kg} \mathrm{ha}^{-1}$.

\section{Food Consumption Pattern}

The endline food consumption survey revealed a positive impact of both higher production from recommended cultivation practice and nutrition awareness initiatives. There was an increase of $13 \%$ in average intake of finger millet over the baseline $(70 \mathrm{~g} /$ person/day). There was also an increase in the number of households consuming finger millet in their daily diet to 187 from 172 during the baseline. The proportion of households sourcing it from their own production was also higher at $68 \%$ as against $47 \%$ during the baseline.

\section{Conclusions}

Overall, the significantly higher yield with improved variety and improved agronomic practice portends greater availability of the nutrient-dense crop for consumption in a context where area under finger millet cultivation has been declining. Though finger millet occupies an important position in the diet as well as farming system (e.g. fodder for cattle) of the community in the study area, cultivation of commercial crops or putting the land for other use was seen as an economical option by the household when the return from finger millet was low. This subsequently had implications for household dietary diversity and led to dependence on market for food grains. This intervention demonstrates an economically viable alternative approach for farmers.

An earlier study had reported reduced time for care work for women during peak agricultural seasons [14]. The reduced drudgery of work for women demonstrated under this approach will make more time available for child care and leisure. Coupled with better nutrition awareness, the increased availability will help ensure better consumption of nutrient-rich finger millet by the households. Selling the surplus will provide additional income to the growers as well as increase availability for non-growers. By 2017-2018 kharif, improved variety, GPU-67, with improved package and practice was being cultivated by 167 farmers in 58 ac in seven core study villages and by 87 farmers in 27 ac in eighteen other villages. Triple-layered bags were distributed among the farmers for safe storage of seeds. A village-level seed bank was also established for timely availability of quality seeds and to help farmers in distress. Small-scale village-level millet processing mills were also installed to encourage farmers to process and consume their produce.

Given that a large part of India is under rainfed farming and finger millet is primarily a crop that is grown in marginal and sub-marginal rainfed lands, the scope to increase the area and production of this climate-resilient and lesswater-requiring nutritious cereal is immense. Appropriate policy direction and support is required for this. Mini-kit demonstrations and training programmes at different levels will help in popularizing newly released varieties among farmers and ensuring their availability to replace the lowyielding local varieties. As discussed in the paper, just change in cultivation practices led to substantial improvement in yield even with farmers' varieties. The recommended package of practices such as line transplanting, optimum row spacing, depth of transplanting, age of seedlings, optimum plant population per unit area, timely cultural practices for higher productivity have to be explained to the farmers through on-farm demonstrations and agricultural extension support systems. For instance, the state government of Odisha has undertaken a special 5-year programme for promotion of millets in tribal areas in partnership with non-government organizations (http://www.milletsodisha.com/guidelines.htm). Essentially, the focus of agriculture extension has to shift from rice, wheat and commercial crops to these crops which are often regarded as 'women's crops' and 'coarse cereals' and do not get the attention they deserve. On the research front, the agriculture research system should give importance to research on all aspects of millet cultivation and develop efficient low-cost technology that is accessible to farmers and easy to adopt. For instance, suitable mechanical devices can be developed and promoted to reduce the drudgery 
of women farmers during weeding and harvesting of the crop.

Since the crop is largely grown under subsistence farming system and performs well even with no addition of chemical inputs, they can be promoted as chemical-free or organic millets; this will help them command a good market price and help increase the income of tribal farmers. Village-level millet processing units will support both, better consumption by farmer households and also sale of surplus produce. Training can also be given to women's groups or millet producer groups to prepare millet-based value-added products and market linkage facilitated with both local markets and neighbouring urban areas, thereby strengthening the conservation-cultivation-consumptioncommerce chain.

The National Food Security Act (2013) provides for the inclusion of millets in government food distribution programmes like the Public Distribution System (PDS), midday meal in schools and Supplementary Nutrition Programme (SNP) under the Integrated Child Development Services (ICDS). The state of Karnataka commenced providing millets under the PDS from 2014. But the challenge seems to lie in ensuring availability of sufficient quantity for procurement [13]. Millet is a component of the fortified pre-mix manufactured and given as take home ration in many states under the SNP of ICDS. At least one milletbased meal a week can be made mandatory under the Midday Meal Programme in schools and noonmeal at ICDS centres. Some states like Odisha have already commenced doing this. Given that there are a wide variety of millets and production and consumption is spread across the country and considering issues of shelf life, local preference, etc., decentralized procurement linking local farmers to the state institutional feeding programmes is perhaps the way to go. Print and electronic media can be effectively harnessed to communicate messages in local languages relating to both millet cultivation targeting farmers and benefits of millet consumption targeting consumers.

In sum, comprehensive planning with favourable policy formulation mainstreaming the nutrition dimension in agriculture can give a thrust to millet cultivation and contribute to a healthier community practicing climatesmart agriculture. The experience also has wider relevance to other developing countries where millets have been the staple food crop.

Acknowledgements We acknowledge the staff members at Koraput who collected and entered the data. A special thanks to Mr. S Raju for the analysis of food consumption survey data. We also thank Dr. R. Rengalakshmi and Dr. V.R. Prabavathy for their insightful comments and suggestions on the draft version of this paper.
Author Contribution Paper conceptualization, literature survey, compilation and analysis of data were carried out by AP. AKP supervised the field research and collection of data. RVB contributed particularly to Sects. 1 and 4.

Funding This paper is part of the research generated by the Leveraging Agriculture for Nutrition in South Asia (LANSA) research consortium and is funded by UK Aid from the UK government. The views expressed do not necessarily reflect the UK Government's official policies.

\section{Compliance with Ethical Standards}

Conflict of interest The authors declare that they have no conflict of interest.

Ethical Standard The study methods were approved by the Ethics Committee of the Board of Trustees, M S Swaminathan Research Foundation (MSSRF), India.

Informed Consent Oral informed consent was obtained from the head of household before collecting household information and from all subjects selected for nutrition status assessment.

Open Access This article is distributed under the terms of the Creative Commons Attribution 4.0 International License ( http://creativecommons.org/licenses/by/4.0/), which permits unrestricted use, distribution, and reproduction in any medium, provided you give appropriate credit to the original author(s) and the source, provide a link to the Creative Commons license, and indicate if changes were made.

\section{References}

1. Beddington J (2010) Food security: contributions from science to a new and greener revolution. Philos Trans R Soc B Biol Sci 365:61-71

2. Bhaskar AVV, Nithya DJ, Raju S, Bhavani RV (2017) Establishing integrated agriculture-nutrition programmes to diversify household food and diets in rural India. Food Secur 9:981-999

3. Cline WR (2007) Global warming and agriculture: impact estimates by country. Center for Global Development and Peterson Institute for International Economics, Washington, DC

4. Farnandez DR, Vanderjagt DJ, Millson M et al (2013) Fatty acid, amino acid and trace mineral composition of Eleusine coracana (Pwana) seeds from northern Nigeria. Plant Foods Hum Nutr 58:1-10

5. Government of Odisha - GoO (2015) Odisha agriculture statistics (2013-2014). Director of Agriculture and Food Production, Bhubaneswar

6. Gull A, Jan R, Nayik GA, Prasad K, Kumar P (2014) Significance of finger millet in nutrition, health and value added products: a review. J Environ Sci Comput Sci Eng Technol 3:1601-1608

7. Gupta SM, Arora S, Mirza N et al (2017) Finger millet: a "Certain" crop for an "Uncertain" future and a solution to food insecurity and hidden hunger under stressful environments. Front Plant Sci 8:643

8. Lata C (2015) Advances in genomics for enhancing abiotic stress tolerance in millets. Proc Indian Natl Sci Acad 81:397-417

9. Longvah T, Ananthan R, Bhaskarachary K, Venkaiah K (2017) Indian food composition tables. National Institute of Nutrition, ICMR, Hyderabad

10. Mishra CS, Taraputia T, Suchen B (2014) Policy advocacy for climate smart agriculture in Millets: an initiative for ensuring 
food security in tribal communities of Koraput tract, Odisha, India. Global Adv Res J Agric Sci 3(7):179-185

11. Prabhakar A (2014) Pragati, Koraput experiences in system of ragi intensification. http://sri.cals.cornell.edu/countries/india/ orissa/InOdisha_Pragati_SCI\%20_Ragi14.pdf. Accessed 14 May 2018

12. Pradhan A, Panda AK, Bhaskar AVV (2017) Crop based demonstrations and trials under farming system for nutrition study in Koraput (2013-16) - a report. MSSRF research report MSSRF/RR/17/43. http://59.160.153.185/library/sites/default/files/ Crop\%20interventions\%20under\%20FSN-2013-16-Koraput.pdf. Accessed 14 May 2018

13. Rajsekhar SC, Raju S (2017) Introduction of millets in PDS: lessons from Karnataka-a report. MSSRF research report MSSRF/RR/17/41. http://59.160.153.185/library/node/593. Accessed 14 May 2018
14. Rao N, Raju S (2017) Gendered time, seasonality and nutrition: insights from two Indian districts. LANSA working paper Series, vol 22, December. http://59.160.153.185/library/sites/default/ files/Gender\%20time.pdf

15. Shukla A, Lalit A, Sharma V, Vats S, Alam A (2015) Pearl and finger millets: the hope of food security. Appl Res J 1:59-66

16. Singh B, Bahuguna A, Bhatt A (2015) Small millets of Uttarakhand for sustainable nutritional security and biodiversity conservation. Int J Manag Soc Sci Res 4(8):26-30

17. Singh P, Raghuvanshi RS (2012) Finger millet for food and nutritional security. Afr J Food Sci 6(4):77-84

18. Tester M, Langridge P (2010) Breeding technologies to increase crop production in a changing world. Science 327:818-822

19. Thapliyal V, Singh K (2015) Finger millet: potential millet for food security and power house of nutrients. Int J Res Agric For 2(2):22-33 